\title{
Heterologous Expression of the Grapevine JAZ7 Gene in Arabidopsis Confers Enhanced Resistance to Powdery Mildew but Not to Botrytis cinerea
}

\author{
Muhammad Hanif ${ }^{1,2,+}$, Mati Ur Rahman ${ }^{1,2, \dagger}$, Min Gao ${ }^{1,2}$, Jinhua Yang 1,2, Bilal Ahmad ${ }^{1,2}$, \\ Xiaoxiao Yan ${ }^{1,2}$ and Xiping Wang $1,2, *$ (D) \\ 1 State Key Laboratory of Crop Stress Biology in Arid Areas, College of Horticulture, \\ Northwest A\&F University, Yangling 712100, China; mhanif@nwafu.edu.cn (M.H.); \\ mati@nwafu.edu.cn (M.U.R.); gaomin@umbc.edu (M.G.); 13759927085@163.com (J.Y.); \\ bajwa1999@nwafu.edu.cn (B.A.); xiaoxyan@nwafu.edu.cn (X.Y.) \\ 2 Key Laboratory of Horticultural Plant Biology and Germplasm Innovation in Northwest China, \\ Ministry of Agriculture, Northwest A\&F University, Yangling 712100, China \\ * Correspondence: wangxiping@nwsuaf.edu.cn; Tel: +86-29-8708-2129 \\ + These authors contributed equally to this work.
}

Received: 27 October 2018; Accepted: 30 November 2018; Published: 5 December 2018

\begin{abstract}
Jasmonate ZIM-domain (JAZ) family proteins comprise a class of transcriptional repressors that silence jasmonate-inducible genes. Although a considerable amount of research has been carried out on this gene family, there is still very little information available on the role of specific JAZ gene members in multiple pathogen resistance, especially in non-model species. In this study, we investigated the potential resistance function of the VqJAZ7 gene from a disease-resistant wild grapevine, Vitis quinquangularis cv. "Shang-24", through heterologous expression in Arabidopsis thaliana. VqJAZ7-expressing transgenic Arabidopsis were challenged with three pathogens: the biotrophic fungus Golovinomyces cichoracearum, necrotrophic fungus Botrytis cinerea, and semi-biotrophic bacteria Pseudomonas syringae pv. tomato DC3000. We found that plants expressing VqJAZ7 showed greatly reduced disease symptoms for $G$. cichoracearum, but not for $B$. cinerea or $P$. syringae. In response to G cichoracearum infection, VqJAZ7-expressing transgenic lines exhibited markedly higher levels of cell death, superoxide anions $\mathrm{O}_{2}{ }^{-}$, and $\mathrm{H}_{2} \mathrm{O}_{2}$ accumulation, relative to nontransgenic control plants. Moreover, we also tested the relative expression of defense-related genes to comprehend the possible induced pathways. Taken together, our results suggest that $V q J A Z 7$ in grapevine participates in molecular pathways of resistance to G. cichoracearum, but not to B. cinerea or P. syringae.
\end{abstract}

Keywords: VqJAZ7; grapevine; Golovinomyces cichoracearum; powdery mildew; Botrytis cinerea; Pst DC3000

\section{Introduction}

Plants use physical and chemical barriers as the first line of defense against invading pathogens. However, inducible molecular defense strategies are also important for plant survival. These defensive barriers comprise a complex immune system known as innate immunity to defend the plant against pathogen infection. Plasma membrane proteins that are designated pattern-recognition receptors (PRRs) recognize pathogen-associated molecular patterns (PAMPs) and induce a basal resistance response called PAMP-triggered immunity (PTI) [1]. Phytopathogens can suppress PTI using a battery of virulent effector molecules [2,3]. These effector molecules are recognized by a family of polymorphic intracellular receptor complexes called nucleotide-binding/leucine-rich repeat (NLR/NB-LRR) and induce a second phase of the resistance response called effector-triggered immunity (ETI) [4]. ETI is 
strong, robust, and leads to the hypersensitive response (HR), which is a type of programmed cell death (PCD) [5], which decreases the proliferation of the attacking pathogen.

Key signaling molecules in plant defense include the endogenous hormones salicylic acid (SA) and jasmonic acid (JA) [6]. SA-dependent signaling pathways are deployed in response to a broad range of pathogens [7], particularly the biotrophs [8]. JA, in addition to pathogen infection [9-12], works as a defense signal to stress [13], wound responses [14-16], and insect attacks [17,18]. JA also has several endogenous regulatory roles in diverse plant processes, including stamen development [19-23], root growth [24-26], anthocyanin accumulation [27,28], and senescence [29-31]. The SA and JA pathways can interact, both positively and antagonistically. In Arabidopsis thaliana (Arabidopsis), the eds 4 and pad4 mutants, which are impaired in the accumulation of SA, showed enhanced JA-dependent gene expression [32], and other evidence indicates that SA signaling can inhibit JA signaling in tomato [33,34]. On the other hand, the treatment of tobacco plants with Erwinia carotovora elicitors inhibited the expression of SA-related genes [35], suggesting that JA can negatively influence SA signaling. It is also evident from the literature that SA and JA-related genes can be expressed synergistically. For instance, in a microarray study in which Arabidopsis plants were subjected to different defense-inducing treatments, more than 50 genes were regulated by both SA and JA-mediated signaling [36]. Antagonism between SA and JA-mediated signaling pathways might ensure appropriate responses to certain pathogens, for instance, the ability of SA to promote PCD might be prevented by the plant in the case of necrotrophic pathogens, which use cell death for its own benefit [6].

Jasmonate ZIM-domain (JAZ)-family proteins act as negative regulators of JA signaling through repressive physical interaction with MYC2 transcription factors [37-39] and other proteins such as the corepressor TOPLESS (TPL) [26]. When the plant is exposed to abiotic or biotic stress, the JA content in the cell increases, and JA-Ile (Jasmonoyl-L-isoleucine conjugate), the active form of JA, promotes physical interaction between JAZ proteins and coronatine-insensitive 1 (COI1), which targets the proteins to the $26 \mathrm{~S}$ proteasome. The proteolytic degradation of JAZ proteins by the proteasome thus derepresses JA-mediated transcription and downstream processes [37-41].

Since their initial characterization, a substantial amount of research has been done on the function of JAZ genes in reference plants such as Arabidopsis and rice, but only a few studies have focused on horticultural crops such as grape. Grape is one of the most important fruit crops worldwide and is consumed in many forms, i.e., fresh, dried, juice, vinegar, and wine. Most of the high-yielding, improved grape varieties are interspecific hybrids of Vitis vinifera, a species that is highly susceptible to diseases and nematodes. Disease is an important factor limiting yield in grapes, and is commonly addressed by the prodigious use of pesticides. However, pesticides and other chemical inputs increase the cost of production, and can have adverse effects on human health. The use of disease-resistant cultivars is an alternative approach, and in-depth knowledge about defense-related genes and their associated molecular pathways is essential for molecular breeding programs to provide disease-resistance cultivars.

In a previous study, we identified the JAZ7 gene from the common grapevine, Vitis vinifera, as highly induced by various biotic stresses [42]. We identified $11 \mathrm{JAZ}$ genes in the grapevine genome and named them $V v J A Z 1-V v J A Z 11$. We found that these genes showed diverse transcriptional responses to exogenous SA and JA, as well as two additional hormones, ethylene and abscisic acid. Interestingly, the expression of $V v J A Z 7$ was upregulated in response to all four of these hormones. There is very little information available about the function of JAZ7 [43]. In this study, we engineered transgenic Arabidopsis plants expressing the VqJAZ7 gene from the disease-resistant Chinese wild grape V. quinquangularis cv. "Shang-24", and evaluated the plants for resistance to the biotrophic fungus Golovinomyces cichoracearum (a causal agent of powdery mildew), necrotrophic fungus Botrytis cinerea (gray mold), and semi-biotrophic pathogen Pseudomonas syringae pv. tomato DC3000. 


\section{Results}

\subsection{Bioinformatic Information about VqJAZ7 Gene}

To gain insight into the potential functional relationships among JAZ proteins, we carried out a phylogenetic analysis of JAZ proteins from grapevine, Arabidopsis, and rice (Figure 1). VvJAZ7 was grouped with $V v J A Z 8$ within a well-defined clade also containing $V v J A Z 1,3,5,6,8$, and 11, as well as Arabidopsis $J A Z 3,4$, and 9. No rice JAZ member was found within this clade (Figure 1). Other information regarding multiple alignment of the ORF translation sequences of $J A Z 7$ genes from $V$. quinquangularis and $V$. vinifera, multiple alignment of ORF translations of JAZ7 genes from $V$. quinquangularis and $V$. vinifera, and the ORF sequence of the $V q J A Z 7$ gene and its translation were provided in supplementary file (Data S1, Data S2 and Data S3, respectively).

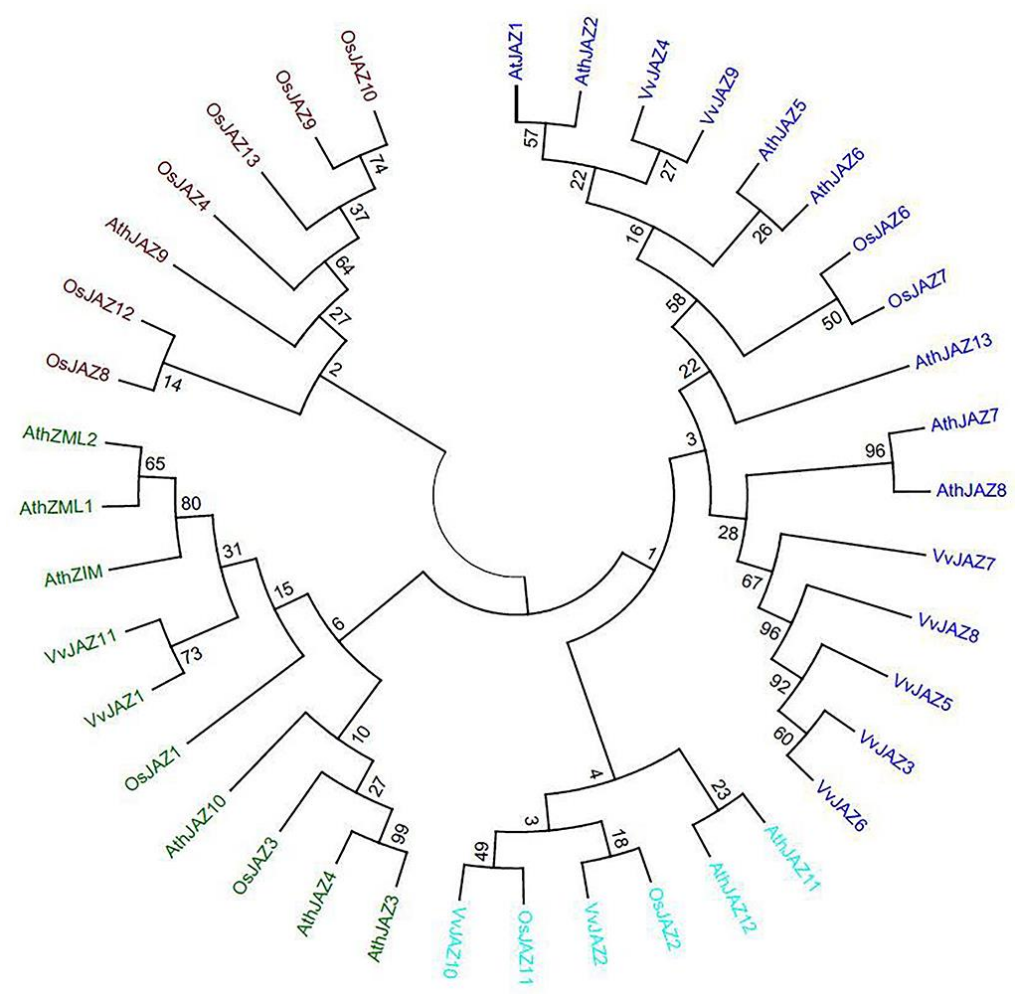

Figure 1. Phylogenetic analysis of Jasmonate ZIM-domain (JAZ) proteins from grapevine, Arabidopsis, and rice. Sequences were aligned and the phylogenetic tree was generated using the neighbor-joining method in ClustalX2 (http: / www.clustal.org/clustal2/). The tree was designed using the online tool Interactive Tree of Life (Version 3 (http:/ / itol.embl.de/). The bootstraps values were calculated with 1000 replicates.

\subsection{Analysis of VqJAZ7 Overexpression Lines}

To evaluate a potential role for $V q J A Z 7$ in pathogen defense, we engineered transgenic Arabidopsis constitutively expressing $V q J A Z 7$, and challenged the plants by inoculation with G. cichoracearum, the causative agent of powdery mildew disease in grape. Eighteen independent transgenic lines were produced, and three highly resistant transgenic lines (TL1, TL2, and TL3) were selected to generate T3 homozygous lines. The transgenic lines were confirmed by PCR (Figure S1). The expression of $V q J A Z 7$ was evaluated in these three transgenic lines after G. cichoracearum inoculation. We found that, even though $V q J A Z 7$ was engineered to be expressed constitutively in the transgenic lines, VqJAZ7 transcript levels increased after infection, reaching a maximum of $\sim 4$.6-fold increase at three days post-inoculation (dpi) and then declining (Figure 2). 


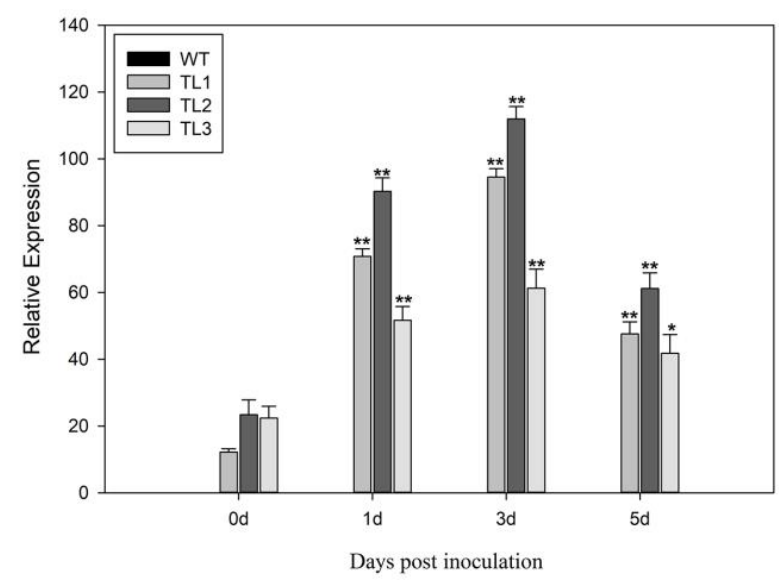

Figure 2. Expression of $V q J A Z 7$ following inoculation with G. cichoracearum. The VqJAZ7 expression levels post G. cichoracearum inoculation in nontransgenic Arabidopsis and transgenic lines TL1, TL2, and TL3. The $V q J A Z 7$ expression levels increased gradually from 0 days post-inoculation (dpi) and peaked at three dpi. The VqJAZ7 transcript levels were 0 in wild-type (WT) plants. The data are means $\pm \mathrm{SD}$ from three experiments. Asterisks indicate statistical significance $\left({ }^{* *}: p<0.01, * * p<0.05\right.$, one-way analysis of variance (ANOVA)).

\subsection{Arabidopsis VqJAZ7 Transgenic Lines Show Enhanced Resistance to Powdery Mildew}

To evaluate the potential for $V q J A Z 7$ in defense against G. cichoracearum, we inoculated plants with the pathogen and evaluated the effects at seven dpi. In VqJAZ7-expressing transgenic lines, fewer disease symptoms were observed than in nontransgenic controls (Figure 3A). To explore the mechanisms by which enhanced resistance to G. cichoracearum might be imparted, we stained leaves with trypan blue, nitro blue tetrazolium (NBT), and diaminobenzidine (DAB) to assess levels of cell death, superoxide anions $\left(\mathrm{O}_{2}^{-}\right)$, and $\mathrm{H}_{2} \mathrm{O}_{2}$, respectively. As shown in Figure 3, VqJAZ7-expressing transgenic lines exhibited markedly higher levels of cell death, superoxide anions $\left(\mathrm{O}_{2}{ }^{-}\right)$, and $\mathrm{H}_{2} \mathrm{O}_{2}$ accumulation, relative to nontransgenic control plants.
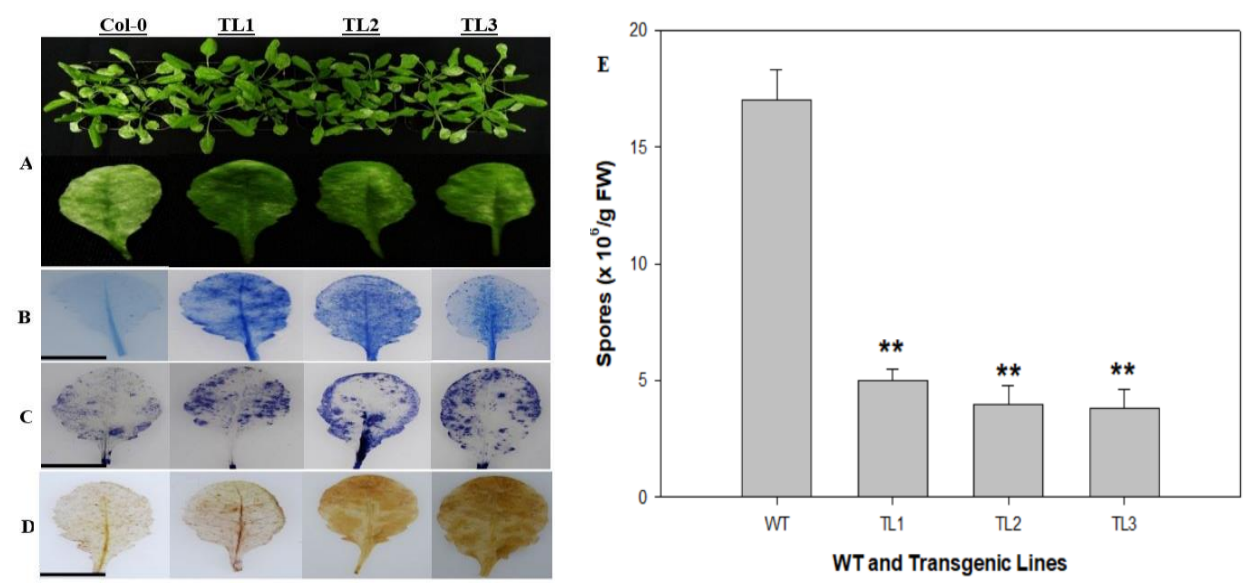

Figure 3. Effects of heterologous $V q J A Z 7$ expression in transgenic Arabidopsis on powdery mildew symptoms. VqJAZ7 transgenic lines (TL1, TL2, and TL3) and nontransgenic control (Col-0) were infected with powdery mildew, and disease symptoms were visualized at seven dpi. (A) Images of aerial parts (above) and representative leaves (below) of plants at seven dpi; (B-D) Trypan blue, nitro blue tetrazolium (NBT), and diaminobenzidine (DAB) staining were carried out on leaves five dpi in order to detect cell death (B); superoxide anion accumulation (C); and $\mathrm{H}_{2} \mathrm{O}_{2}$ (D); respectively. Scale bars $=10 \mathrm{~mm}$; (E) Spore number per gram of fresh leaves. Data bars are means $\pm \mathrm{SD}$ from three independent experiments. Asterisks show statistical significance between overexpressing lines and nontransgenic control (** $p<0.01$, Student's $t$-test). 
To help define the molecular pathways by which VvJAZ7 may contribute powdery mildew (PM) resistance to Arabidopsis, we evaluated the expression levels of a cadre of genes previously shown to be SA-responsive or JA-responsive, in response to PM infection (Figure 4). The SA-dependent disease resistance genes isochorismate synthase 1 (AtICS1) and pathogenesis-related gene 1 (AtPR1), were significantly upregulated after PM infection in transgenic plants (Figure 4A). The SA signal is transduced via NPR1, which interacts with transcription factors participating in SA-mediated pathogenesis related (PR) gene expression [44,45], and PR1 is a marker gene for systemic acquired resistance (SAR) in Arabidopsis [46]. In our study, the expression level of AtPR1 was downregulated in the nontransgenic control plants; however, its expression was significantly upregulated, $\sim$ threefold at one dpi and sevenfold at later time points in the transgenic lines when compared to control plants. AtICS1 is involved in the biosynthesis and accumulation of SA [47]. We found that its expression was upregulated both in the transgenic and control plants, but the expression in control plants was still very low relative to transgenic lines. AtICS1 was upregulated $~ 4.5$-fold, 2.8-fold and 5.7-fold at one, three, and five dpi, respectively, in transgenic lines as compared to control plants (Figure 4A). Furthermore, the transcript levels of lipoxygenase-3 (AtLOX3), which is involved in JA formation [48,49], was downregulated at all time points, with $\sim 5.8$-fold down-regulation at 5 dpi. Plant defensin 1.2 (AtPDF1.2), which mediates methyl jasmonates (MeJA) signaling [50], was also downregulated, 8.3-fold at one dpi to 6.1-fold at five dpi, as compared to nontransgenic control plants (Figure 4B).
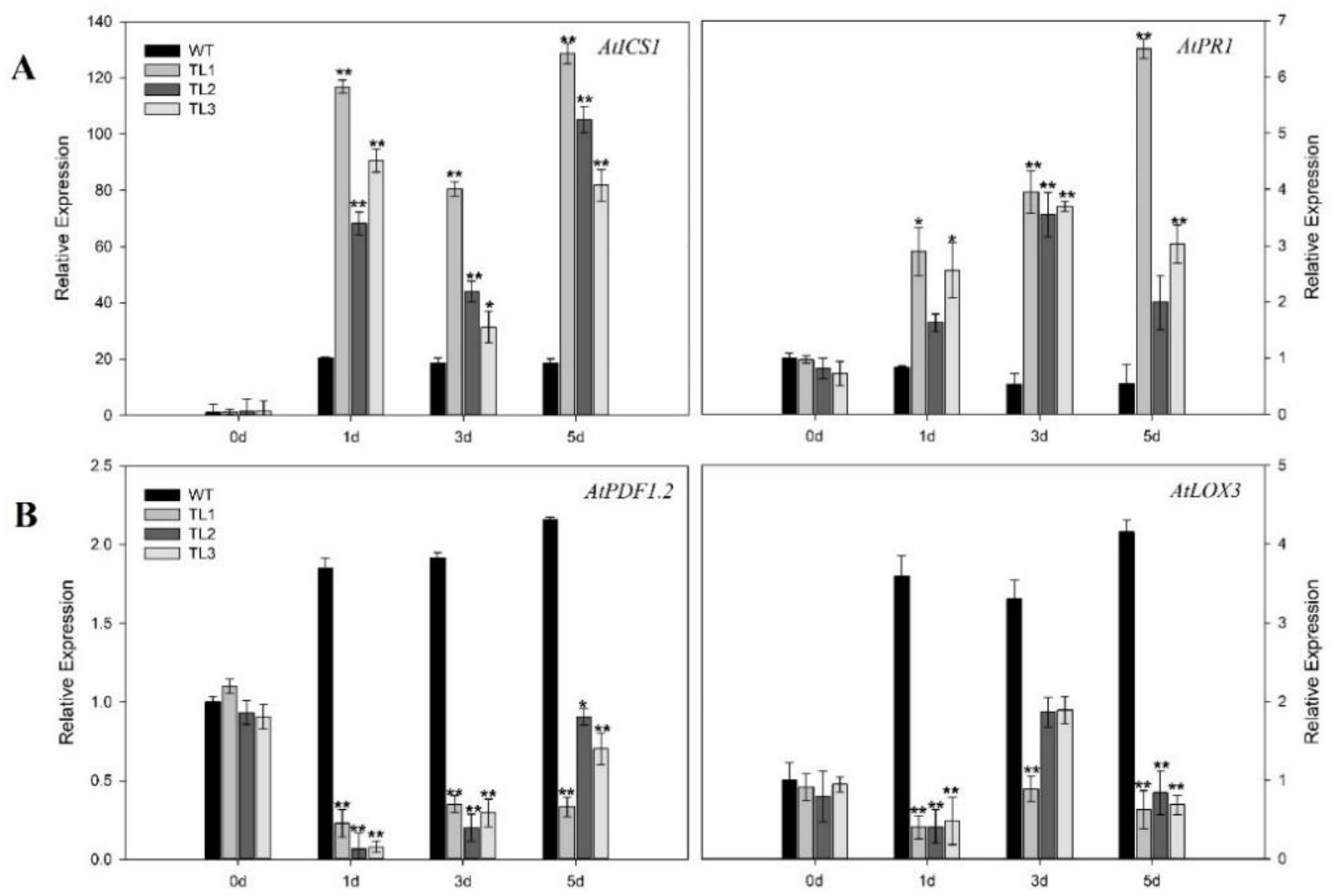

Figure 4. Relative expression of defense-related genes SA-dependent (A) and JA-dependent (B) in PM-infected leaves at zero, one, three, and five days post-inoculation (dpi) via qPCR. Data represent mean values \pm SD from three independent experiments. Asterisks indicate significant differences between nontransgenic control plants (Col-0) and transgenic lines (TL) at different time points $(* *: p<0.01, *: p<0.05$, Student's $t$-test).

\subsection{Heterologous Expression of VqJAZ7 in Arabidopsis Decreased Resistance to B. Cinerea}

To assess the effect of the heterologous expression of VqJAZ7 regarding defense to other pathogens, we challenged transgenic plants with the necrotrophic fungal pathogen, B. cinerea. At $72 \mathrm{~h}$ 
post-inoculation (hpi), we noted lesions on all of the tested plants; however, transgenic lines showed more prominent disease lesions than nontransgenic control plants (Figure 5A), with bigger lesion diameters (Figure 5D). In the transgenic lines, the proportion of large lesions was significantly greater than in the nontransgenic controls (Figure 5E). Since necrotrophic pathogens ultimately kill infected cells, we performed the histochemical staining of infected plants. Compared with controls, more cell death and $\mathrm{H}_{2} \mathrm{O}_{2}$ production were evident in leaves from transgenic plants (Figure 5B,C). Moreover, the activities of antioxidant enzymes catalase (CAT), peroxidase (POD), and superoxide dismutase (SOD) were lower in the leaves of the transgenic plants. We noted highest values of CAT, POD, and SOD at $48 \mathrm{hpi}, 72 \mathrm{hpi}$, and $24 \mathrm{hpi}$, respectively (Figure 5F-H).
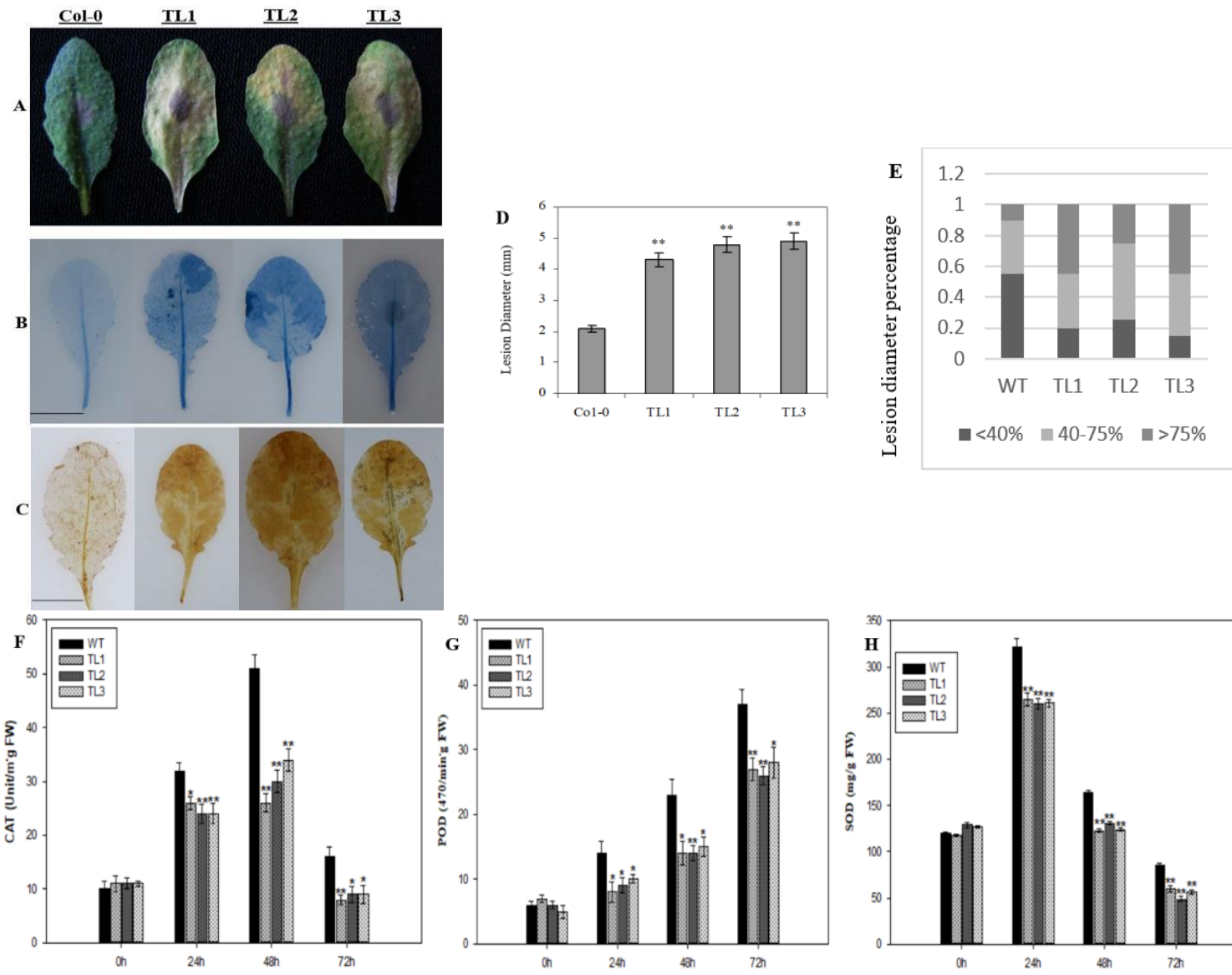

Figure 5. Effects of heterologous VqJAZ7 expression in transgenic Arabidopsis on B. cinerea symptoms and defense-related enzyme activity. VqJAZ7 transgenic lines (TL1, TL2, and TL3) and nontransgenic controls (Col-0) were infected with B. cinerea (A) Images of plants at $72 \mathrm{~h}$ post-inoculation (hpi). Trypan blue and DAB staining were carried out on leaves $72 \mathrm{hpi}$ in order to detect cell death (B); and $\mathrm{H}_{2} \mathrm{O}_{2}$ (C), respectively. Scale bars $=10 \mathrm{~mm}$; (D) Botrytis average lesion diameter at $72 \mathrm{hpi}$; (E) Symptoms on transgenic and control lines 72 hpi with B. cinerea. Activity of catalase (CAT) (F); peroxidase (POD) $(\mathrm{G})$ and superoxide dismutase (SOD) (H) in the leaves of transgenic and WT plants. Asterisks indicate significant difference between nontransgenic (NT) and transgenic lines ${ }^{* *}: p<0.01,{ }^{*}: p<0.05$, Student's $t$-test).

To gain insight into the apparent decrease in resistance to $B$. cinerea conferred by VqJAZ7, we evaluated the expression of the defense-related genes AtPR1, AtICS1, AtPDF1.2, and AtLOX3 in response to $B$. cinerea at $0 \mathrm{hpi}, 24 \mathrm{hpi}, 48 \mathrm{hpi}$, and $72 \mathrm{hpi}$ (Figure 6) in transgenic and control plants. AtICS1 was expressed to 9.9-fold and sevenfold higher levels in VqJAZ7 transgenic lines compared to controls at $48 \mathrm{hpi}$ and $72 \mathrm{hpi}$ (Figure 6A). Likewise, the expression of AtPR1 was elevated 4.4-fold and 4.1 -fold at $48 \mathrm{hpi}$ and $72 \mathrm{hpi}$, respectively, in the transgenic plants. In contrast, the expression of 
JA-related genes, AtPDF1.2 and AtLOX3, was significantly lower in transgenic lines as compared to controls (Figure 6B) at all of the time points post-infection. AtPDF1.2 and AtLOX3 were both expressed differentially, but this expression was lower than that of the control plants.

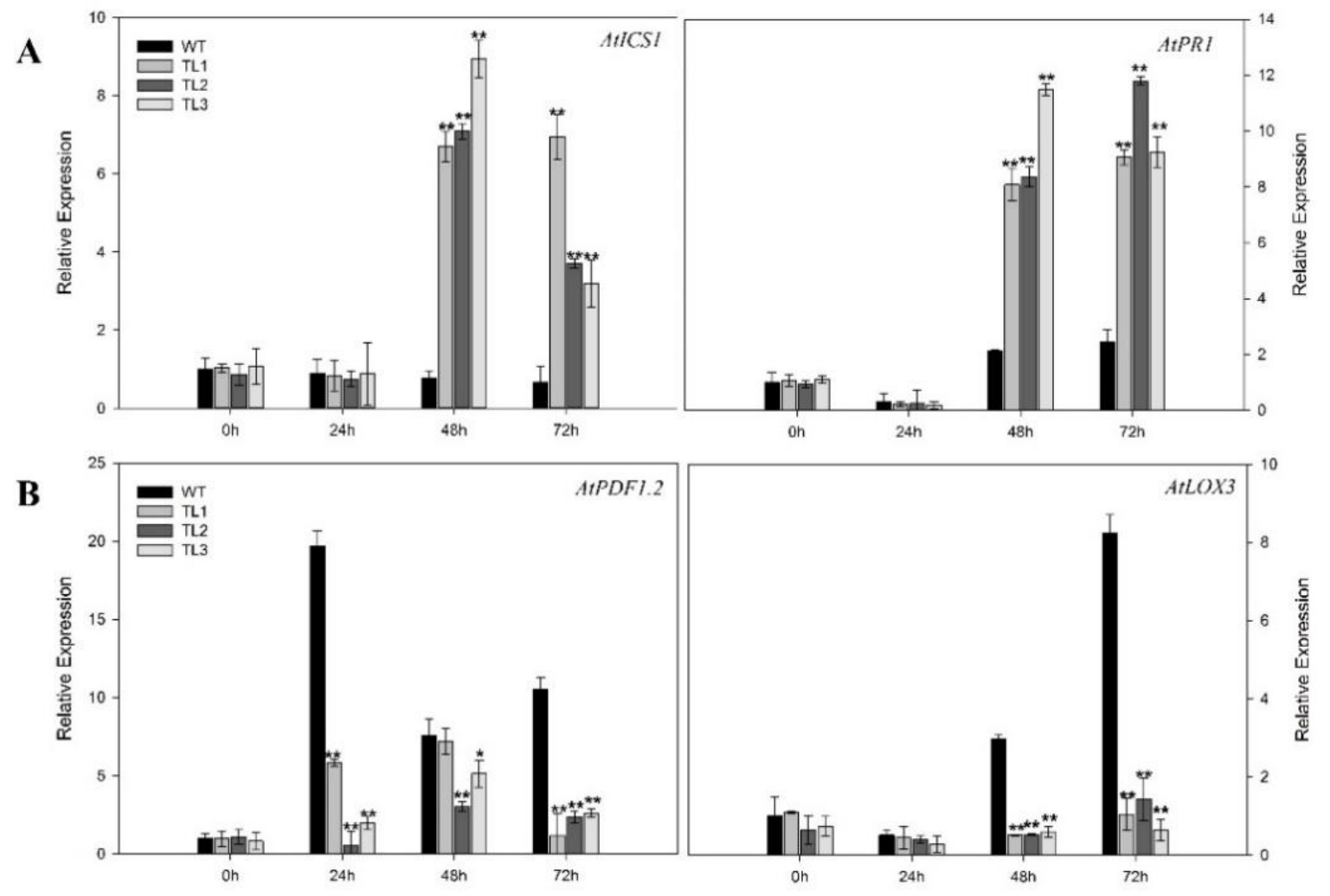

Figure 6. Relative expression of defense-related genes in SA-dependent (A) and JA-dependent (B) leaves infected by B. cinerea at 0 hpi, 24 hpi, 48 hpi, and 72 hpi. Expression was evaluated using qPCR. Data represent mean values \pm SD from three independent experiments. Asterisks indicate significant differences between transgenic lines and controls $\left({ }^{* *}: p<0.01,{ }^{*}: p<0.05\right.$, Student's $t$-test).

\subsection{Heterologous Expression of VqJAZ7 in Arabidopsis Decreased Resistance to Pst DC3000}

To investigate a potential influence of VqJAZ7 on resistance to Pst DC3000, transgenic Arabidopsis lines overexpressing VqJAZ7 and nontransgenic control plants were inoculated with Pst DC3000. All of the plants were examined $72 \mathrm{hpi}$. Relative to nontransgenic control plants, more disease symptoms were observed in the VqJAZ7-expressing plants (Figure 7A). We noted less cell death in the transgenic lines as measured by trypan blue staining (Figure 7B). We also observed lower $\mathrm{O}_{2}{ }^{-}$accumulation in the transgenic lines, as evaluated by NBT staining (Figure 7C). This might result from decreased cell death in the transgenic lines. We counted the bacterial population per unit of leaf area (Figure 7D) to assess the growth of the pathogen at 72 hpi. As shown in Figure 7, higher numbers of bacteria were found on the leaves of the transgenic lines as compared with controls.

We also evaluated the expression of AtPR1, AtICS1, AtPDF1.2 and AtLOX3 in response to Pst DC3000, at $0 \mathrm{hpi}, 24 \mathrm{hpi}, 48 \mathrm{hpi}$, and $72 \mathrm{hpi}$, (Figure 8), in transgenic and control plants. In nontransgenic control plants, AtICS1 showed strong and transient induction at $48 \mathrm{hpi}$, with decreased expression at $72 \mathrm{hpi}$ (Figure 8). In all three transgenic lines, AtICS1 was strongly induced by $24 \mathrm{hpi}$, with decreased expression at subsequent time points. AtPR1, AtPDF1.2, and AtLOX3 were all strongly induced by 24 hpi in nontransgenic control plants (Figure 8). However, these genes were not induced, or induced to substantially decreased levels, in all three transgenic lines. 
A

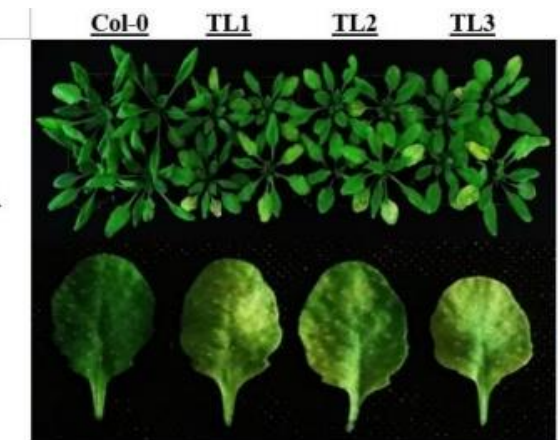

B
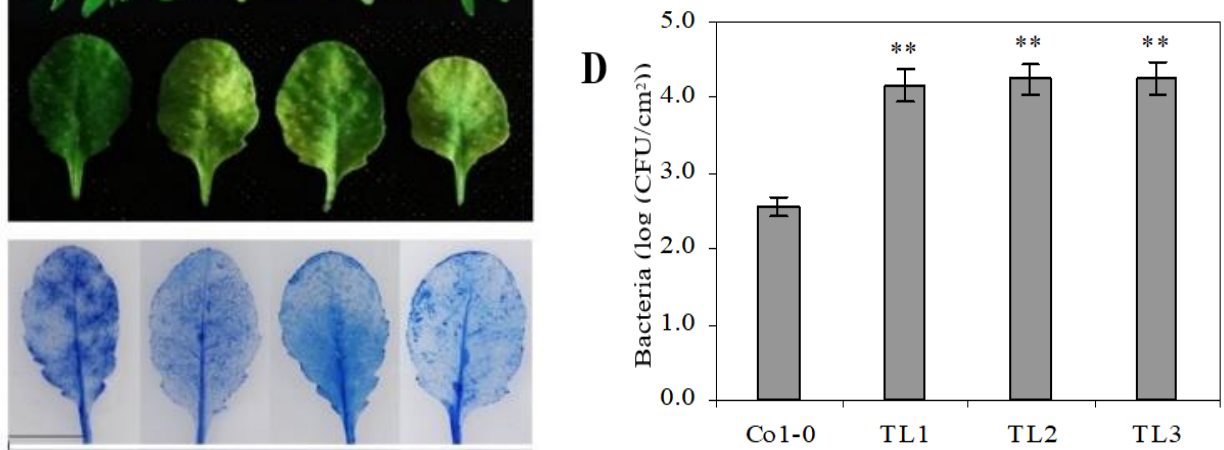

C

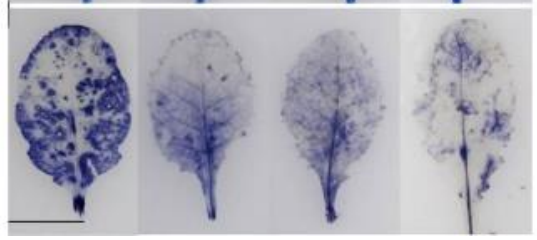

Figure 7. Effects of heterologous VqJAZ7 expression in transgenic Arabidopsis on PST DC3000 pathogenicity. VqJAZ7 transgenic lines (TL1, TL2, and TL3) and nontransgenic controls (Col-0) were infected with DC3000. (A) Images of aerial portions of whole plants (above) and representative leaves (below) at $72 \mathrm{hpi}$; (B, C) Assays for cell death (B) and superoxide (C) at $72 \mathrm{hpi} \mathrm{using} \mathrm{trypan} \mathrm{blue} \mathrm{and}$ NBT staining, respectively. Scale bars $=10 \mathrm{~mm}$; (D) Pst DC3000 bacterial population at 72 hpi. Asterisks indicate significant difference between control and transgenic lines ( ${ }^{* *} p<0.01$, Student's $t$-test).

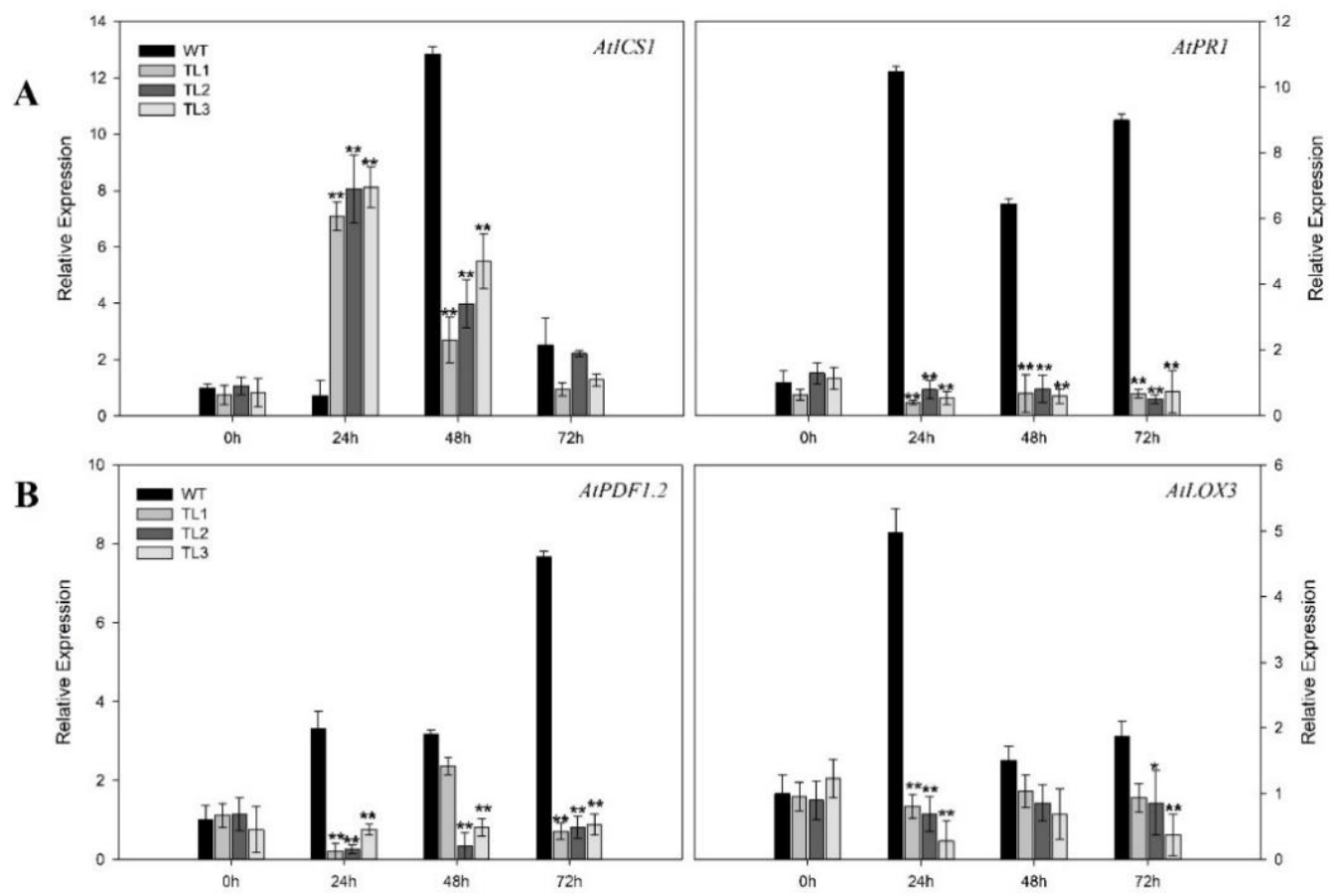

Figure 8. Relative expression of defense-related genes SA-dependent (A) and JA-dependent (B) in leaves infected by Pst DC3000 at 0 hpi, 24 hpi, 48 hpi, and 72 hpi. Expression was evaluated using Q-RTPCR. Data represent mean values \pm SD from three independent experiments. Asterisks indicate significant differences between control and transgenic lines $\left({ }^{* *}: p<0.01,{ }^{*}: p<0.05\right.$, Student's $t$-test). 


\subsection{Expressing VqJAZ7 in Arabidopsis Decreased Elicitor-Dependent Callose Accumulation}

The plant cell wall acts a barrier against attacking pathogens. Upon stress stimuli, plants modify and remodel the cell wall to incorporate defense-related polysaccharides, such as the 1,3- $\beta$-glucan callose [51]. We applied Pst DC3000 bacteria or the defense response elicitors flg22 and lipopolysaccharide (LPS) to the control and transgenic plants and stained them with aniline blue. As shown in Figure 9, the control plants accumulated substantially more callose than the transgenic lines.

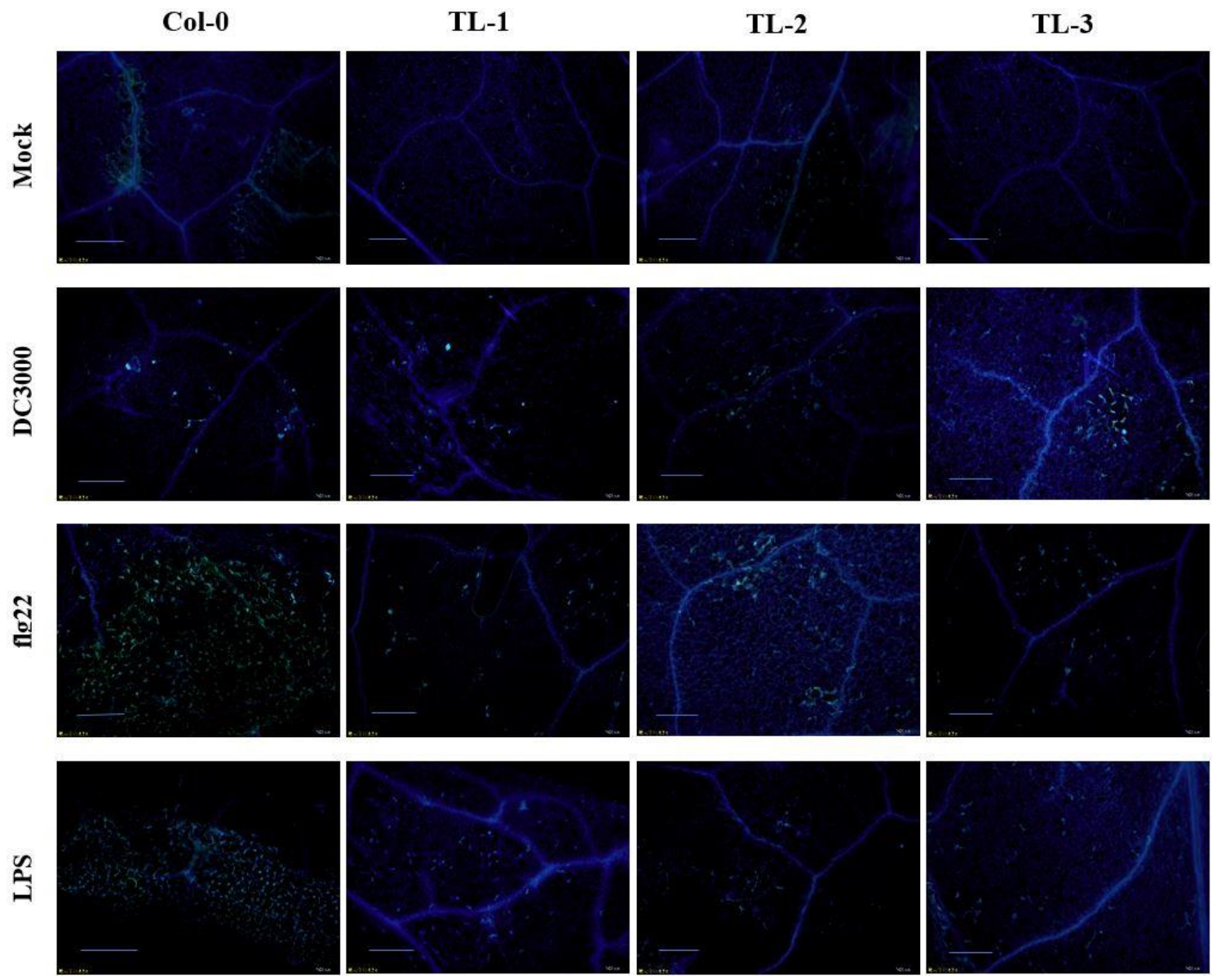

Figure 9. Effects of heterologous VqJAZ7 expression in transgenic Arabidopsis on callose deposition. All samples were stained with aniline blue after Pst DC3000, flg22, or LPS application. All of the experiments were repeated three times with six infected leaves per repetition. The scale bar indicates $100 \mu \mathrm{m}$.

\section{Materials and Methods}

\subsection{Plant and Pathogen Material and Growth Conditions}

Vitis quinquangularis cv. "Shang-24" plants were maintained in a curated Vitis collection at Northwest A\&F University, Yangling, Shaanxi, China. Two-year-old plants were used in this study. Wild-type Arabidopsis thaliana Col-0 plants were grown at $21^{\circ} \mathrm{C}$ and $60 \%$ relative humidity in long-day photoperiods (16 h-light and eight h-dark). Arabidopsis pad4 mutant plants were also grown under these conditions for the culturing of G. cichoracearum. B. cinerea was isolated from $V$. vinifera cv. Red Globe and propagated on potato glucose agar at $22{ }^{\circ} \mathrm{C}$. The P. syringae pv. tomato DC3000 strain (Pst DC3000) was stored for long-term use at $-80^{\circ} \mathrm{C}$. 


\subsection{Bioinformatic Analyses}

Curated open reading frame (ORF) translations from Arabidopsis, grapevine, and rice were as maintained by the National Center for Biotechnological Information (http:/ / blast.ncbi.nlm.nih.gov/ Blast.cgi) and the J. Craig Venture Institute (http://www.tigr.org/). Sequences were aligned and the phylogenetic tree was constructed using the neighbor joining (NJ) method in ClustalX2 (http: //www.clustal.org/clustal2/). The tree was designed using an online tool (Interactive Tree Of Life, Version 3; (http:/ /itol.embl.de/) [52,53]. The bootstrap values were calculated with 1000 replicates.

\subsection{Extraction of RNA from Grapevine Leaves and Semi-Quantitative RT-PCR}

Total RNA was extracted from V. quinquangularis cv. "Shang-24" according to the protocol of Huang et al., 2016 [54]. First strand cDNA was synthesized from two $\mu \mathrm{g}$ of total RNA with the Primer Script ${ }^{\mathrm{TM}}$ RTase according to the supplied protocol (TaKaRa Bio Inc., Dalian, China). cDNA was amplified using $2 \times$ Taq PCR Master Mix (Bio Sci Biotech, Hangzhou, China) and oligonucleotide primers designed to specifically amplify the $V q J A Z$ or $V v J A Z$ transcripts (Table S1). Grapevine ACTIN1 was used as a reference gene. Reactions were conducted with the following parameters: $94{ }^{\circ} \mathrm{C}$ for eight minutes, followed by $30-40$ cycles of $92{ }^{\circ} \mathrm{C}$ for $30 \mathrm{~s}, 58-64{ }^{\circ} \mathrm{C}$ for $30 \mathrm{~s}, 72{ }^{\circ} \mathrm{C}$ for $30 \mathrm{~s}$, and a final extension at $72{ }^{\circ} \mathrm{C}$ for eight minutes. PCR products were separated on a $1 \%(w / v)$ agarose gel and imaged under UV light to analyze gene expression. All of the reactions were repeated three times.

\subsection{Plant Transformation}

The VqJAZ7 full-length coding sequence ( $417 \mathrm{bp}$ ) was amplified by PCR using gene-specific primers F1 (5'-GAGGAAGCCCCCAAGAGCAACA-3') and R1 (5'- TTC TGA AGG AAC CGA TGG AGC G-3') and $2 \times$ Taq PCR Master Mix (Bio Sci Biotech, Hangzhou, China). The resulting product was cloned into the pGEM $^{\circledR}$-T Easy vector (Promega, Madison, WI, USA), and cloned sequence was confirmed as error-free by sequencing. This plasmid was named pGEM-T/VqJAZ7. Subsequently, the VqJAZ7 coding sequence was amplified from the pGEM-T/VqJAZ7 plasmid using primers F2 and R2 (Table S1), which introduced KpnI and XbaI restriction sites within F2 (5'-CGC TCTAGAATGGAGTTTACCCCCAATC-3' XbaI site underlined) and R2 (5'-GGCGGTACCTTAATGATTGTATGGGGACAT-3' KpnI site underlined), respectively. After the VqJAZ7 coding sequence had been excised from pGEM-T/VqJAZ7 and purified, it was inserted downstream of the CaMV $35 S$ promoter in the plant overexpression vector pCambia2300 (Cambia, Brisbane, QLD, Australia), and this plasmid was introduced into Arabidopsis by the floral dip method [55]. $\mathrm{T}_{1}$ seeds were collected and sown on MS medium containing $10 \mathrm{~g} / \mathrm{L}$ sucrose, eight $\mathrm{g} / \mathrm{L}$ agar at $\mathrm{pH} 5.8$, supplemented with $75 \mathrm{mg} / \mathrm{L}$ kanamycin to screen transgenic lines. A total of 18 independent lines were obtained, and the three lines showing the strongest apparent resistance to PM (TL1, TL2, and TL3) were selected for further study. Presence of the transgene was confirmed with PCR. Homozygous T3 lines were generated for all further experiments.

\subsection{Pathogen Inoculation Assays}

G. cichoracearum was maintained on live plants of phytoalexin deficient 4 (pad4), a PM-susceptible Arabidopsis mutant [56]. Transgenic and nontransgenic control plants were inoculated with G. cichoracearum by the method of Guo et al. [57]. Three days following inoculation, plants were transferred to an ambient environment of $22{ }^{\circ} \mathrm{C}$ and $40 \%$ RH. Samples were collected at 0 , one day, three days, five days, and seven days post-inoculation (dpi) for gene expression analysis. Visual scoring of disease severity and spore counting were performed as described previously [58].

B. cinerea was cultured on potato dextrose agar medium at $25^{\circ} \mathrm{C}$ in the dark. Conidial spore suspension was prepared in distilled water as described previously [59]. Leaves from 21 four-week-old transgenic and nontransgenic control plants were placed on wet filter paper set on $1 \%$ agarose in a tray. The leaves were inoculated by dropping $10 \mu \mathrm{L}$ of spore suspension $\left(2 \times 10^{6}\right.$ conidia $\left./ \mathrm{mL}\right)$ 
onto the adaxial surface, and the trays were then sealed with a transparent plastic film to maintain high humidity. Samples were collected at 0 hpi, 24 hpi, 48 hpi, and 72 hpi, and lesion diameter was determined at $72 \mathrm{hpi}$. Measurements of lesion diameter and antioxidant enzyme activity were carried out as described by Guo et al. [57].

Pst DC3000 was grown according to the method of Tornero and Dangl [60] in a rotating incubator at $280 \mathrm{rpm}$ and $28^{\circ} \mathrm{C}$ in King's B medium containing $50 \mathrm{mg} / \mathrm{mL}$ rifampicin. When cultures reached an $\mathrm{OD}_{600}$ of $0.8-1.0$, they were subjected to centrifugation at $5000 \times \mathrm{g}$ for $10 \mathrm{~min}$, and cells were resuspended in $10 \mathrm{mM}$ of $\mathrm{MgCl}_{2}$ to an $\mathrm{OD}_{600}$ of 0.02 . Four-week-old plants were dipped into the cell suspension containing $0.02 \%$ Silwet L-77 for 10 minutes, as described previously [60]. Plants were incubated at $90 \%$ relative humidity for $24 \mathrm{~h}$, and then transferred to ambient growth conditions. Disease severity was evaluated at three dpi.

To detect callose accumulation, four-week old plants were subjected to pressure infiltration with flg22, Pst DC3000, or LPS with a needleless syringe. $\mathrm{MgCl}_{2}(10 \mathrm{mM})$ was used for mock inoculation. Samples were collected $18 \mathrm{~h}$ later, and stained with aniline blue as described by Wang et al. [61].

\subsection{Histochemical Detection}

Histochemical detection was carried out as according to Yan et al. [59] using nine leaves each from the transgenic lines and nontransgenic control. To visualize cell death, leaves were subjected to staining with trypan blue (TB); $\mathrm{O}_{2}{ }^{-}$accumulation was assessed using six $\mathrm{mM}$ of nitro blue tetrazolium (NBT); $\mathrm{H}_{2} \mathrm{O}_{2}$ accumulation was visualized with one $\mathrm{mg} \cdot \mathrm{mL}^{-1}$ diaminobenzidine (DAB, $\mathrm{pH}$ 3.8). The TB buffer consisted of $10 \mathrm{~mL}$ of phenol, $10 \mathrm{~mL}$ of lactic acid, $10 \mathrm{~mL}$ of $\mathrm{ddH}_{2} \mathrm{O}, 20 \mathrm{~mL}$ of ethanol, and $10 \mathrm{mg}$ of trypan blue. Leaves were first boiled in TB solution for three minutes, and then decolorized in $2.5 \mathrm{mg} \cdot \mathrm{mL}^{-1}$ of chloral hydrate for $48 \mathrm{~h}$. NBT $(6 \mathrm{mM})$ was dissolved in HEPES buffer, $\mathrm{pH}$ 7.5. Samples were soaked in NBT solution for two hours and in DAB solution for eight hours, and then decolorized in $80 \%$ ethanol for two hours at $60^{\circ} \mathrm{C}$. Samples were kept at room temperature for $48 \mathrm{~h}$, and finally transferred to $50 \%$ glycerol for histochemical studies.

\subsection{Quantitative Real-Time PCR}

Leaf samples were harvested at $0 \mathrm{dpi}$, one dpi, three dpi, five dpi, and seven dpi for PM; and $0 \mathrm{hpi}, 24 \mathrm{hpi}, 48 \mathrm{hpi}$, and $72 \mathrm{hpi}$ for B. cinerea; and 0 hpi, 24 hpi, 48 hpi, and 72 hpi for Pst DC3000. Three biological replicates were collected from each treatment at each time point and immediately frozen in liquid nitrogen. Total RNA was extracted from the samples using the E.Z.N.A. ${ }^{\circledR}$ Plant RNA Kit (Omega Bio-tech, Norcross, GA, USA), and first-strand cDNA was synthesized using PrimerScript ${ }^{\mathrm{TM}}$ RTase (TaKaRa BioInc., Dalian, China). Quantitative real-time PCR was performed in triplicate in a final reaction volume of $20 \mu \mathrm{L}$, which contained one $\mu \mathrm{L}$ of a six fold cDNA dilution as template and $2 \times$ Taq PCR MasterMix (BioSci Biotech, Hangzhou, China). Assays were carried out using a Step OnePlus real-time PCR system (Applied Biosystems, Life Technologies, Singapore) and the following thermal profile: $94{ }^{\circ} \mathrm{C}$ for $30 \mathrm{~s}$, followed by 35 cycles of $94{ }^{\circ} \mathrm{C}$ for $5 \mathrm{~s}$, and $60{ }^{\circ} \mathrm{C}$ for $30 \mathrm{~s}$. The Arabidopsis ACTIN2 gene was used as an internal reference.

\subsection{Statistical Analysis}

Data analysis was performed using Microsoft Excel and Sigma Plot (10.0, Systat, Inc., San Jose, CA, USA). Significance of differences were assessed by paired $t$-tests through one-way ANOVA using SPSS Statistics 17.0 software (IBM China Company Ltd., Beijing, China).

\section{Discussion}

JAZ family proteins comprise a small family of 13 members in Arabidopsis [62], and have been characterized as transcriptional repressors of early response genes in JA signaling. JAZ proteins consist of two highly conserved motifs: the Jas motif, which is required for JAZ-COI1 interactions and degradation in response to JA-Ile [38,63-65], and the TIFY/ZIM domain, which is required for JAZ 
homodimerization and heterodimerization [63]. The repression of gene expression occurs at low levels of JA, because $M Y C s$ transcription factors are bound to the JAZ proteins with the help of corepressors, such as NINJA or TPL $[14,26,66]$. After the perception of an external stimulus, the amount of active JAs (JA-Ile) increases, and the JAZ proteins are bound by the F-box signal receptor COI1, and are thereby tagged for degradation by the $26 \mathrm{~S}$ proteasome $[39,67]$. Upon $J A Z s^{\prime}$ degradation, MYC proteins are freed to activate the JA signaling and responses [68]. JAZ7 is one of the most enigmatic members among the 13 JAZs in Arabidopsis [69], because it does not form homodimers or heterodimers, and its interaction is limited to very few transcription factors, e.g., MYC3 and MYC4 [70,71]. Moreover, $J A Z 7$ contains the highly conserved EAR motif [72], suggesting that JAZ7 may not require NINJA to recruit TPL [73]. Direct interaction has been identified between TPL and JAZ8, a close homolog of $J A Z 7$, by the Arabidopsis interactome study [74].

Plants are exposed to biotic and abiotic stresses throughout their life, and due to their sessile nature, they have evolved complex defense mechanisms to survive. Plants respond to stresses by a simple way, but it recruits a complex network of antagonistic or synergistic nature between SA and JA for its immune system $[75,76]$.

In this study, we investigated the potential role of grapevine JAZ7 in defense against G. cichoracearum, B. cinerea, and Pst DC3000, through its heterologous expression in Arabidopsis. As for as the biotrophic fungal disease powdery mildew, fewer disease symptoms were observed in transgenic lines compared with nontransgenic controls at seven dpi (Figure 3A). This result was further supported by trypan blue (Figure 3B), NBT (Figure 3C), and DAB (Figure 3D) staining, which indicated a higher level of cell death, more superoxide anions $\left(\mathrm{O}_{2}{ }^{-}\right)$, and $\mathrm{H}_{2} \mathrm{O}_{2}$ accumulation, respectively, in transgenic lines. This histochemical staining result further suggested that transgenic lines resisted G. cichoracearum infection by causing more cell death, which is a limiting factor to biotrophic pathogens. Our results are in agreement with Dickman and Fluhr [5], who reported that PCD followed the hypersensitive response (HR) after the pathogen invasion of a host plant. HR is induced by the host plant as the first line of defense. Also, in the case of prolonged stress conditions, there is increased reactive oxygen species (ROS) accumulation and decreased photosynthesis, which can result in the induction of downstream PCD pathways [77]. We observed that AtICS1 and AtPR1, the SA-dependent disease resistance genes, were significantly upregulated in transgenic plants after PM infection (Figure 4A). This indicates that $J A Z 7$ may contribute to resistance to powdery mildew by promoting the expression of SA-mediated genes. Wildermuth et al. [78] reported that after pathogen invasion in Arabidopsis, the majority of the SA is produced from chorismate through the isochorismate pathway by the expression of ICS1 and ICS2. Secondly, post-pathogen invasion is a hypersensitive response that increases SA levels to trigger SAR. On the other hand, AtLOX3 and AtPDF1.2 were expressed to lower levels after PM infection (Figure $4 B$ ), suggesting the suppression of JA signaling.

In contrast, in the case of $B$. cinerea, fewer disease symptoms were observed on nontransgenic control plants than on transgenic lines expressing VqJAZ7 at 72 hpi (Figure 5A). We also found significantly larger lesions on transgenic lines as compared to WT plants (Figure 5D). Previous studies have demonstrated that necrotrophic fungi induced PCD (e.g., Cochliobolus victoriae, a causal agent of Victoria blight disease in oats) [79]. After an attack by a pathogen, plants induce HR as the first line of defense, but this HR is utilized by the necrotrophs for their benefit, because HR has been proved to increase pathogenicity by offering a growth substrate to the B. cinerea [80]. We also measured the transcript levels of defense-related genes, including AtPR1, AtICS1, AtPDF1.2, and AtLOX3 in response to $B$. cinerea at $0 \mathrm{hpi}, 24 \mathrm{hpi}, 48 \mathrm{hpi}$, and $72 \mathrm{hpi}$, (Figure 6), to gain understanding of the pathways by which resistance may be mediated. After inoculation with B. cinerea, AtICS1 was expressed to $\sim 9.9$-fold and sevenfold higher in VqJAZ7 transgenic lines compared to control plants at 48 hpi and $72 \mathrm{hpi}$, respectively. Likewise, the expression of AtPR1 was elevated 4.4-fold and 4.1-fold at $48 \mathrm{hpi}$ and $72 \mathrm{hpi}$, respectively, in the transgenic plants (Figure 6). In contrast, AtPDF1.2 and AtLOX3 were expressed to lower levels in transgenic lines as compared to controls (Figure 6) at all of the time points post-infection. AtPDF1.2 and AtLOX3 were both expressed differentially, but this expression was 
lower than in nontransgenic control plants. Several studies showed that in the case of necrotrophic pathogen attack, plants defend themselves by deploying JA-dependent defense responses [81,82], but on the other hand, several studies have shown that SA antagonizes JA-dependent defenses when accumulated endogenously, and subsequently prioritize SA-dependent resistance to JA-dependent defense [83]. PDF1.2 is strongly suppressed by SA [84,85], and this antagonism was also observed in a large number of accessions in Arabidopsis [86]. Contrasting roles were noted for JA signaling and JA-mediated defense in Arabidopsis to F. oxysporum resistance, e.g., the mutation of MYC2 and LBD20, which are transcription factors, or the overexpression of the ERF1 and AtERF2, JA-defense activators, resulted in the upregulation of JA-dependent defense genes and increased resistance to F. oxysporum $[87,88]$. On the other hand, non-defensive aspects of JA-mediated senescence enhanced susceptibility to this pathogen $[88,89]$. Thatcher et al. [89] studied this closely, and proposed that both defensive and non-defensive JA-signaling are activated following F. oxysporum infection in wild-type plants, but with a significant role of non-defensive aspects to disease outcome.

Active PCD promotes the infection of B. cinerea in the host [90]. In the case of a necrotrophic pathogen such as B. cinerea, ROS exhibited susceptibility in the host plant, and its accumulation at later time points directly benefited the fungus [91]. From previous studies, it is evident that $B$. cinerea generates ROS in plants as a mechanism to facilitate its invasion $[90,92,93]$. We also noted more cell death (Figure 5B) and higher levels of $\mathrm{H}_{2} \mathrm{O}_{2}$ (Figure 5C) in transgenic lines compared with control plants, indicating that $B$. cinerea induced cell death and produced more $\mathrm{H}_{2} \mathrm{O}_{2}$. We also noted that the activities of antioxidant enzymes were lower in the VqJAZ7 transgenic lines than in the nontransgenic control lines, which further indicated that the heterologous expression of $V q J A Z 7$ promoted B. cinerea disease progression.

VqJAZ7 transgenic plants were also less resistant to infection by Pst DC3000 (Figure 7A). Histochemical staining with trypan blue (Figure 7B) and NBT $\left(\mathrm{O}_{2}{ }^{-}\right)$(Figure $7 \mathrm{C}$ ) indicated high levels of cell death and the accumulation of more superoxide anions in nontransgenic control plants as compared to VqJAZ7 transgenic lines when infected with Pst DC3000. Some pathogens developed the capacity to produce hormone mimics [87], which imitate the phytohormones in structure and function to hijack the defense regulatory network of plants for their own benefit. This hormonal divergence activates improper defense responses. For example, $P$. syringae produces coronatine, which is a mimic of JA-Ile, hence suppressing SA-mediated defense responses and promoting disease symptoms in Arabidopsis [22,89]. It is evident from genetic studies that jasmonates antagonize SA-mediated plant defenses [94,95]. In the same way, in our study, both SA-dependent and JA-dependent genes were downregulated after $P$. syringae infection. Coronatine production by $P$. syringae might not only suppress SA-mediated gene expression, but also repress the expression of JA-mediated genes due to the structural and functional similarity between coronatine and JA-Ile. Several studies have suggested that coronatine can suppress local and systemic defenses, resulting in tissue chlorosis and necrosis [96-99]. We also challenged the VqJAZ7 transgenic plants with defense-response elicitors, including the peptide flg22 [100], and lipopolysaccharide, which serves as a stimulant of innate immunity [101]. We found that the transgenic plants accumulated less callose than controls after the injection of Pst DC3000, LPS and flg22 (Figure 9), which further validates that the overexpression $V q J A Z 7$ resulted in susceptibility to this pathogen.

Finally, our result concludes that VqJAZ7 from the disease-resistant, Chinese wild grapevine, $V$. quinquangularis cv. "Shang-24", can increase resistance to plant diseases. We found that transgenic Arabidopsis lines expressing VqJAZ7 enhanced resistance to G. cichoracearum and activated SA signaling. We also found enhanced susceptibility against B. cinerea and Pst DC3000, which may be because of the VqJAZ7 transgenic lines' antagonistic effect on SA-dependent and JA-dependent pathways. Our study shows that $V q J A Z 7$ is activated by biotic stress. Future research will investigate the transcriptional networks and underlying regulatory mechanisms associated with VqJAZ7 defense responses to different pathogens. 
Supplementary Materials: Available online supporting material. Data S1: Multiple alignment of the ORF translation sequences of $J A Z 7$ genes from $V$. quinquangularis and V. vinifera. Data S2: Multiple alignment of ORF translations of $J A Z 7$ genes from $V$. quinquangularis and $V$. vinifera. Data S3: The ORF sequence of the VqJAZ7 gene and its translation. Table S1: Primers used for analysis of JA- and SA-associated genes in Arabidopsis. Figure S1: Characterization of the VqJAZ7 over-expression in Arabidopsis.

Author Contributions: X.W., M.H., and M.U.R. designed the experiments. M.H., M.U.R. and J.Y. conducted the experiments. M.G. helped in RT-PCR. X.W. and M.H. supplied materials/analyses. X.W. provided guidance throughout the study. B.A. and X.Y. helped in histochemical staining. M.H. and X.W. wrote the manuscript. All authors approved the final manuscript.

Funding: This work was supported by the National Natural Science Foundation of China (31572110), as well as the Program for Innovative Research Team of Grape Germplasm Resources and Breeding (2013KCT-25).

Conflicts of Interest: The authors declare no conflict of interest.

\section{References}

1. Monaghan, J.; Zipfel, C. Plant pattern recognition receptor complexes at the plasma membrane. Curr. Opin. Plant Biol. 2012, 15, 349-357. [CrossRef] [PubMed]

2. Karasov, T.L.; Horton, M.W.; Bergelson, J. Genomic variability as a driver of plant-pathogen coevolution? Curr. Opin. Plant Biol. 2015, 18, 24-30. [CrossRef] [PubMed]

3. Anil, K.; Das, S.N.; Podile, A.R. Induced defense in plants: A short overview. Proc. Natl. Acad. Sci. India Sect. B Biol. Sci. 2014, 84, 669-679. [CrossRef]

4. Cui, H.; Tsuda, K.; Parker, J.E. Effector-Triggered Immunity: From Pathogen Perception to Robust Defense. Annu. Rev. Plant Biol. 2015, 66, 487-511. [CrossRef] [PubMed]

5. Dickman, M.B.; Fluhr, R. Centrality of Host Cell Death in Plant-Microbe Interactions. Annu. Rev. Phytopathol. 2013, 51, 543-570. [CrossRef] [PubMed]

6. Kunkel, B.N.; Brooks, D.M. Cross talk between signaling pathways in pathogen defense. Curr. Opin. Plant Biol. 2002, 5, 325-331. [CrossRef]

7. Durrant, W.E.; Dong, X. Systemic Acquired Resistance. Annu. Rev. Phytopathol. 2004, 42, 185-209. [CrossRef]

8. Spoel, S.H.; Johnson, J.S.; Dong, X. Regulation of tradeoffs between plant defenses against pathogens with different lifestyles. Proc. Natl. Acad. Sci. USA 2007, 104, 18842-18847. [CrossRef]

9. Farmer, E.E.; Alméras, E.; Krishnamurthy, V. Jasmonates and related oxylipins in plant responses to pathogenesis and herbivory. Curr. Opin. Plant Biol. 2003, 6, 372-378. [CrossRef]

10. Xiao, S.; Dai, L.; Liu, F.; Wang, Z.; Peng, W.; Xie, D. COS1: An Arabidopsis coronatine insensitive1 suppressor essential for regulation of jasmonate-mediated plant defense and senescence. Plant Cell 2004, 16, 1132-1142. [CrossRef]

11. Wasternack, C. Jasmonates: An update on biosynthesis, signal transduction and action in plant stress response, growth and development. Ann. Bot. 2007, 100, 681-697. [CrossRef] [PubMed]

12. Browse, J. Jasmonate Passes Muster: A Receptor and Targets for the Defense Hormone. Annu. Rev. Plant Biol. 2009, 60, 183-205. [CrossRef]

13. Rao, M.V.; Lee, H.; Creelman, R.A.; Mullet, J.E.; Davis, K.R. Jasmonic acid signaling modulates ozone-induced hypersensitive cell death. Plant Cell 2000, 12, 1633-1646. [CrossRef] [PubMed]

14. Reymond, P. Differential Gene Expression in Response to Mechanical Wounding and Insect Feeding in Arabidopsis. Plant Cell 2000, 12, 707-720. [CrossRef] [PubMed]

15. Schilmiller, A.L.; Howe, G.A. Systemic signaling in the wound response. Curr. Opin. Plant Biol. 2005, 8, 369-377. [CrossRef] [PubMed]

16. Robson, F.; Okamoto, H.; Patrick, E.; Harris, S.-R.; Wasternack, C.; Brearley, C.; Turner, J.G. Jasmonate and Phytochrome A Signaling in Arabidopsis Wound and Shade Responses Are Integrated through JAZ1 Stability. Plant Cell 2010, 22, 1143-1160. [CrossRef]

17. McConn, M.; Creelman, R.A.; Bell, E.; Mullet, J.E.; Browse, J. Jasmonate is essential for insect defense in Arabidopsis. Proc. Natl. Acad. Sci. USA 1997, 94, 5473-5477. [CrossRef]

18. Farmer, E.E. Surface-to-air signals. Nature 2001, 411, 854-856. [CrossRef]

19. McConn, M.; Browse, J. The Critical Reqarirement for Linslenic Acid Is Pollen Develspment, Not Photosynthesis, in an Arabidopsis Mutant. Plant Cell 1996, 8, 403-416. [CrossRef] 
20. Sanders, P.M. The Arabidopsis DELAYED DEHISCENCE1 Gene Encodes an Enzyme in the Jasmonic Acid Synthesis Pathway. Plant Cell 2000, 12, 1041-1062. [CrossRef]

21. Stintzi, A.; Browse, J. The Arabidopsis male-sterile mutant, opr3, lacks the 12-oxophytodienoic acid reductase required for jasmonate synthesis. Proc. Natl. Acad. Sci. USA 2000, 97, 10625-10630. [CrossRef]

22. Cheng, H.; Song, S.; Xiao, L.; Soo, H.M.; Cheng, Z.; Xie, D.; Peng, J. Gibberellin acts through jasmonate to control the expression of MYB21, MYB24, and MYB57 to promote stamen filament growth in arabidopsis. PLoS Genet. 2009, 5, 20-22. [CrossRef] [PubMed]

23. Chua, L.; Shan, X.; Wang, J.; Peng, W.; Zhang, G.; Xie, D. Proteomics study of COI1-regulated proteins in arabidopsis flower. J. Integr. Plant Biol. 2010, 52, 410-419. [CrossRef] [PubMed]

24. Staswick, P.E.; Su, W.; Howell, S.H. Methyl jasmonate inhibition of root growth and induction of a leaf protein are decreased in an Arabidopsis thaliana mutant. Proc. Natl. Acad. Sci. USA 1992, 89, 6837-6840. [CrossRef] [PubMed]

25. Feys, B.J.F.; Benedetti, C.E.; Penfold, C.N.; Turner, J.G. Arabidopsis Mutants Selected for Resistance to the Phytotoxin Coronatine Are Male Sterile, Insensitive to Methyl Jasmonate, and Resistant to a Bacterial Pathogen. Plant Cell 1994, 6, 751-759. [CrossRef] [PubMed]

26. Pauwels, L.; Barbero, G.F.; Geerinck, J.; Tilleman, S.; Grunewald, W.; Pérez, A.C.; Chico, J.M.; Bossche, R.V.; Sewell, J.; Gil, E.; et al. NINJA connects the co-repressor TOPLESS to jasmonate signalling. Nature 2010, 464, 788-791. [CrossRef] [PubMed]

27. Franceschi, V.R.; Grimes, H.D. Induction of soybean vegetative storage proteins and anthocyanins by low-level atmospheric methyl jasmonate. Proc. Natl. Acad. Sci. USA 1991, 88, 6745-6749. [CrossRef]

28. Shan, X.; Zhang, Y.; Peng, W.; Wang, Z.; Xie, D. Molecular mechanism for jasmonate-induction of anthocyanin accumulation in arabidopsis. J. Exp. Bot. 2009, 60, 3849-3860. [CrossRef]

29. Ueda, J.; Kato, J. Isolation and Identification of a Senescence-promoting Substance from Wormwood (Artemisia absinthium L.). Plant Physiol. 1980, 66, 246-249. [CrossRef]

30. Schommer, C.; Palatnik, J.F.; Aggarwal, P.; Chételat, A.; Cubas, P.; Farmer, E.E.; Nath, U.; Weigel, D. Control of jasmonate biosynthesis and senescence by miR319 targets. PLoS Biol. 2008, 6, 1991-2001. [CrossRef]

31. Shan, X.; Wang, J.; Chua, L.; Jiang, D.; Peng, W.; Xie, D. The Role of Arabidopsis Rubisco Activase in Jasmonate-Induced Leaf Senescence. Plant Physiol. 2011, 155, 751-764. [CrossRef] [PubMed]

32. Gupta, V.; Willits, M.G.; Glazebrook, J. Arabidopsis thaliana EDS4 Contributes to Salicylic Acid (SA)-Dependent Expression of Defense Responses: Evidence for Inhibition of Jasmonic Acid Signaling by SA. Mol. Plant-Microbe Interact. 2000, 13, 503-511. [CrossRef] [PubMed]

33. Pena-Cortés, H.; Albrecht, T.; Prat, S.; Weiler, E.W.; Willmitzer, L. Aspirin prevents wound-induced gene expression in tomato leaves by blocking jasmonic acid biosynthesis. Planta 1993, 191, 123-128. [CrossRef]

34. Doares, S.H.; Narvaez-Vasquez, J.; Conconi, A.; Ryan, C.A. Salicylic Acid Inhibits Synthesis of Proteinase Inhibitors in Tomato Leaves Induced by Systemin and Jasmonic Acid. Plant Physiol. 1995, 108, 1741-1746. [CrossRef] [PubMed]

35. Vidal, S.; De León, I.P.; Denecke, J.; Palva, E.T. Salicylic acid and the plant pathogen Erwinia carotovora induce defense genes via antagonistic pathways. Plant J. 1997, 11, 115-123. [CrossRef]

36. Schenk, P.M.; Kazan, K.; Wilson, I.; Anderson, J.P.; Richmond, T.; Somerville, S.C.; Manners, J.M. Coordinated plant defense responses in Arabidopsis revealed by microarray analysis. Proc. Natl. Acad. Sci. USA 2000, 97, 11655-11660. [CrossRef]

37. Yan, Y.; Stolz, S.; Chetelat, A.; Reymond, P.; Pagni, M.; Dubugnon, L.; Farmer, E.E. A Downstream Mediator in the Growth Repression Limb of the Jasmonate Pathway. Plant Cell 2007, 19, 2470-2483. [CrossRef]

38. Thines, B.; Katsir, L.; Melotto, M.; Niu, Y.; Mandaokar, A.; Liu, G.; Nomura, K.; He, S.Y.; Howe, G.A.; Browse, J. JAZ repressor proteins are targets of the SCFCOI1 complex during jasmonate signalling. Nature 2007, 448, 661-665. [CrossRef]

39. Chini, A.; Fonseca, S.; Fernández, G.; Adie, B.; Chico, J.M.; Lorenzo, O.; García-Casado, G.; López-Vidriero, I.; Lozano, F.M.; Ponce, M.R.; et al. The JAZ family of repressors is the missing link in jasmonate signalling. Nature 2007, 448, 666-671. [CrossRef]

40. Yan, J.; Zhang, C.; Gu, M.; Bai, Z.; Zhang, W.; Qi, T.; Cheng, Z.; Peng, W.; Luo, H.; Nan, F.; et al. The Arabidopsis CORONATINE INSENSITIVE1 Protein Is a Jasmonate Receptor. Plant Cell 2009, 21, 2220-2236. [CrossRef] 
41. Katsir, L.; Schilmiller, A.L.; Staswick, P.E.; He, S.Y.; Howe, G.A. COI1 is a critical component of a receptor for jasmonate and the bacterial virulence factor coronatine. Proc. Natl. Acad. Sci. USA 2008, 105, 7100-7105. [CrossRef] [PubMed]

42. Zhang, Y.; Gao, M.; Singer, S.D.; Fei, Z.; Wang, H.; Wang, X. Genome-Wide Identification and Analysis of the TIFY Gene Family in Grape. PLoS ONE 2012, 7, e44465. [CrossRef] [PubMed]

43. Yu, J.; Zhang, Y.; Di, C.; Zhang, Q.; Zhang, K.; Wang, C.; You, Q.; Yan, H.; Dai, S.Y.; Yuan, J.S.; et al. JAZ7 negatively regulates dark-induced leaf senescence in Arabidopsis. J. Exp. Bot. 2016, 67, 751-762. [CrossRef]

44. Cao, H.; Bowling, S.A.; Gordon, A.S. Characterization of an Arabidopsis Mutant That $1 \mathrm{~s}$ Nonresponsive to lnducers of Systemic Acquired Resistance. Plant Cell 1994, 6, 1583-1592. [CrossRef] [PubMed]

45. Kinkema, M.; Fan, W.; Dong, X. Nuclear Localization of NPR1 Is Required for Activation of PR Gene Expression. Plant Cell 2000, 12, 2339. [CrossRef] [PubMed]

46. Uknes, S. Acquired Resistance in Arabidopsis. Plant Cell 1992, 4, 645-656. [CrossRef]

47. Strawn, M.A.; Marr, S.K.; Inoue, K.; Inada, N.; Zubieta, C.; Wildermuth, M.C. Arabidopsis isochorismate synthase functional in pathogen-induced salicylate biosynthesis exhibits properties consistent with a role in diverse stress responses. J. Biol. Chem. 2007, 282, 5919-5933. [CrossRef]

48. Caldelari, D.; Wang, G.; Farmer, E.E.; Dong, X. Arabidopsis lox3 lox4 double mutants are male sterile and defective in global proliferative arrest. Plant Mol. Biol. 2011, 75, 25-33. [CrossRef]

49. Chauvin, A.; Caldelari, D.; Wolfender, J.L.; Farmer, E.E. Four 13-lipoxygenases contribute to rapid jasmonate synthesis in wounded Arabidopsis thaliana leaves: A role for lipoxygenase 6 in responses to long-distance wound signals. New Phytol. 2013, 197, 566-575. [CrossRef]

50. Xu, X.; Chen, C.; Fan, B.; Chen, Z. Physical and Functional Interactions between and WRKY60 Transcription Factors. Plant Cell 2006, 18, 1310-1326. [CrossRef]

51. Ton, J.; Mauch-Mani, B. $\beta$-amino-butyric acid-induced resistance against necrotrophic pathogens is based on ABA-dependent priming for callose. Plant J. 2004, 38, 119-130. [CrossRef] [PubMed]

52. Letunic, I.; Bork, P. Interactive Tree of Life v2: Online annotation and display of phylogenetic trees made easy. Nucleic Acids Res. 2011, 39, 475-478. [CrossRef] [PubMed]

53. Serres-Giardi, L.; Belkhir, K.; David, J.; Glémin, S. Patterns and Evolution of Nucleotide Landscapes in Seed Plants. Plant Cell 2012, 24, 1379-1397. [CrossRef] [PubMed]

54. Huang, L.; Zhang, S.; Singer, S.D.; Yin, X.; Yang, J. Expression of the Grape VqSTS21 Gene in Arabidopsis Confers Resistance to Osmotic Stress and Biotrophic Pathogens but Not Botrytis cinereal. Front. Plant Sci. 2016, 7, 1379. [CrossRef] [PubMed]

55. Clough, S.J.; Bent, A.F. Floral dip: A simplified method for Agrobacterium-mediated transformation of Arabidopsis thaliana. Plant J. 1998, 16, 735-743. [CrossRef] [PubMed]

56. Reuber, T.L.; Plotnikova, J.M.; Dewdney, J.; Rogers, E.E.; Wood, W.; Ausubel, F.M. Correlation of defense gene induction defects with powdery mildew susceptibility in Arabidopsis enhanced disease susceptibility mutants. Plant J. 1998, 16, 473-485. [CrossRef] [PubMed]

57. Guo, R.; Tu, M.; Wang, X.; Zhao, J.; Wan, R.; Li, Z. Plant Science Ectopic expression of a grape aspartic protease gene, AP13, in Arabidopsis thaliana improves resistance to powdery mildew but increases susceptibility to Botrytis cinerea. Plant Sci. 2016, 248, 17-27. [CrossRef] [PubMed]

58. Li, H.; Xu, Y.; Xiao, Y.; Zhu, Z. Expression and functional analysis of two genes encoding transcription factors, VpWRKY1 and VpWRKY2, isolated from Chinese wild Vitis pseudoreticulata. Planta 2010, 232, 1325-1337. [CrossRef]

59. Yan, X.; Qiao, H.; Zhang, X.; Guo, C.; Wang, M. Analysis of the grape (Vitis vinifera L.) thaumatin-like protein (TLP) gene family and demonstration that TLP29 contributes to disease resistance. Sci. Rep. 2017, 7, 4269. [CrossRef]

60. Tornero, P.; Dangl, J.L. A high-throughput method for quantifying growth of phytopathogenic bacteria in Arabidopsis thaliana. Plant J. 2001, 28, 475-481. [CrossRef]

61. Wang, M.; Zhu, Y.; Han, R.; Yin, W.; Guo, C.; Li, Z.; Wang, X. Expression of vitis amurensis VaERF20 in arabidopsis thaliana improves resistance to Botrytis cinerea and Pseudomonas syringae pv. Tomato DC3000. Int. J. Mol. Sci. 2018, 19, 696. [CrossRef] [PubMed]

62. Thireault, C.; Shyu, C.; Yoshida, Y. Repression of jasmonate signaling by a non-TIFY JAZ protein in Arabidopsis. Plant J. 2015, 82, 669-679. [CrossRef] [PubMed] 
63. Chini, A.; Fonseca, S.; Chico, J.M.; Fernández-Calvo, P.; Solano, R. The ZIM domain mediates homo- and heteromeric interactions between Arabidopsis JAZ proteins. Plant J. 2009, 59, 77-87. [CrossRef] [PubMed]

64. Chung, H.S.; Howe, G.A. A Critical Role for the TIFY Motif in Repression of Jasmonate Signaling by a Stabilized Splice Variant of the JASMONATE ZIM-Domain Protein JAZ10 in Arabidopsis. Plant Cell 2009, 21, 131-145. [CrossRef] [PubMed]

65. Melotto, M.; Mecey, C.; Niu, Y.; Chung, H.S.; Katsir, L.; Yao, J.; Zeng, W.; Thines, B.; Staswick, P.; Browse, J.; et al. A critical role of two positively charged amino acids in the Jas motif of Arabidopsis JAZ proteins in mediating coronatine- and jasmonoyl isoleucine-dependent interactions with the COI1 F-box protein. Plant J. 2008, 55, 979-988. [CrossRef] [PubMed]

66. Dombrecht, B.; Xue, G.P.; Sprague, S.J.; Kirkegaard, J.A.; Ross, J.J.; Reid, J.B.; Fitt, G.P.; Sewelam, N.; Schenk, P.M.; Manners, J.M.; et al. MYC2 Differentially Modulates Diverse Jasmonate-Dependent Functions in Arabidopsis. Plant Cell 2007, 19, 2225-2245. [CrossRef] [PubMed]

67. Yan, J.; Li, H.; Li, S.; Yao, R.; Deng, H.; Xie, Q.; Xie, D. The Arabidopsis F-Box Protein CORONATINE INSENSITIVE1 Is Stabilized by SCFCOI1 and Degraded via the 26S Proteasome Pathway. Plant Cell 2013, 25. [CrossRef]

68. Turner, J.G.; Ellis, C.; Devoto, A. The jasmonate signal pathway. Plant Cell 2002, 14, S153-S164. [CrossRef]

69. Shyu, C. Unwinding JAZ7-Enigma to harmony. J. Exp. Bot. 2016, 67, 3183-3185. [CrossRef]

70. Fernández-Calvo, P.; Chini, A.; Fernández-Barbero, G.; Chico, J.-M.; Gimenez-Ibanez, S.; Geerinck, J.; Eeckhout, D.; Schweizer, F.; Godoy, M.; Franco-Zorrilla, J.M.; et al. The Arabidopsis bHLH Transcription Factors MYC3 and MYC4 Are Targets of JAZ Repressors and Act Additively with MYC2 in the Activation of Jasmonate Responses. Plant Cell 2011, 23, 701-715. [CrossRef]

71. Thatcher, L.F.; Cevik, V.; Grant, M.; Zhai, B.; Jones, J.D.G.; Manners, J.M.; Kazan, K. Characterization of a JAZ7 activation-tagged Arabidopsis mutant with increased susceptibility to the fungal pathogen Fusarium oxysporum. J. Exp. Bot. 2016, 67, 2367-2386. [CrossRef] [PubMed]

72. Kagale, S.; Links, M.G.; Rozwadowski, K. Genome-Wide Analysis of Ethylene-Responsive Element Binding Factor-Associated Amphiphilic Repression Motif-Containing Transcriptional Regulators in Arabidopsis. Plant Physiol. 2010, 152, 1109-1134. [CrossRef] [PubMed]

73. Pauwels, L.; Goossens, A. The JAZ Proteins: A Crucial Interface in the Jasmonate Signaling Cascade. Plant Cell 2011, 23, 3089-3100. [CrossRef] [PubMed]

74. Dreze, M.; Carvunis, A.-R.; Charloteaux, B.; Galli, M.; Pevzner, S.J.; Tasan, M.; Ahn, Y.-Y.; Balumuri, P.; Barabasi, A.-L.; Bautista, V.; et al. Evidence for Network Evolution in an Arabidopsis Interactome Map. Science 2011, 333, 601-607. [CrossRef]

75. De Vos, M.; Van Oosten, V.R.; Van Poecke, R.M.P.; Van Pelt, J.A.; Pozo, M.J.; Mueller, M.J.; Buchala, A.J.; Métraux, J.-P.; Van Loon, L.C.; Dicke, M.; Pieterse, C.M.J. Signal Signature and Transcriptome Changes of Arabidopsis During Pathogen and Insect Attack. Mol. Plant-Microbe Interact. 2005, 18, 923-937. [CrossRef] [PubMed]

76. Sato, M.; Tsuda, K.; Wang, L.; Coller, J.; Watanabe, Y.; Glazebrook, J.; Katagiri, F. Network modeling reveals prevalent negative regulatory relationships between signaling sectors in arabidopsis immune signaling. PLoS Pathog. 2010, 6, 1-15. [CrossRef] [PubMed]

77. Gechev, T.S.; Dinakar, C.; Benina, M.; Toneva, V.; Bartels, D. Molecular mechanisms of desiccation tolerance in resurrection plants. Cell. Mol. Life Sci. 2012, 69, 3175-3186. [CrossRef]

78. Wildermuth, M.C.; Dewdney, J.; Wu, G.; Ausubel, F.M. Isochorismate synthase is required to synthesize salicylic acid for plant defence. Nature 2001, 414, 562-565. [CrossRef]

79. Gilbert, B.M.; Wolpert, T.J. Characterization of the LOV1-mediated, victorin-induced, cell-death response with virus-induced gene silencing. Mol. Plant Microbe Interact. 2013, 26, 903-917. [CrossRef]

80. Govrin, E.M.; Levine, A. The hypersensitive response facilitates plant infection by the necrotrophic pathogen Botrytis cinerea. Curr. Biol. 2000, 10, 751-757. [CrossRef]

81. Grant, M.R.; Jones, J.D.G. Hormone (Dis)harmony moulds plant health and disease. Science 2009, 324, 750-752. [CrossRef] [PubMed]

82. Robert-Seilaniantz, A.; Grant, M.; Jones, J.D.G. Hormone Crosstalk in Plant Disease and Defense: More Than Just JASMONATE-SALICYLATE Antagonism. Annu. Rev. Phytopathol. 2011, 49, 317-343. [CrossRef] [PubMed] 
83. Pieterse, C.M.J.; Van der Does, D.; Zamioudis, C.; Leon-Reyes, A.; Van Wees, S.C.M. Hormonal Modulation of Plant Immunity. Annu. Rev. Cell Dev. Biol. 2012, 28, 489-521. [CrossRef] [PubMed]

84. Van Wees, S.C.M.; Luijendijk, M.; Smoorenburg, I.; Van Loon, L.C.; Pieterse, C.M.J. Rhizobacteria-mediated induced systemic resistance (ISR) in Arabidopsis is not associated with a direct effect on expression of known defense-related genes but stimulates the expression of the jasmonate-inducible gene Atvsp upon challenge. Plant Mol. Biol. 1999, 41, 537-549. [CrossRef] [PubMed]

85. Spoel, S.H. NPR1 Modulates Cross-Talk between Salicylate- and Jasmonate-Dependent Defense Pathways through a Novel Function in the Cytosol. Plant Cell 2003, 15, 760-770. [CrossRef] [PubMed]

86. Koornneef, A.; Pieterse, C.M.J. Cross Talk in Defense Signaling. Plant Physiol. 2008, 146, 839-844. [CrossRef]

87. McGrath, K.C.; Dombrecht, B.; Manners, J.M.; Schenk, P.M.; Edgar, C.I.; Maclean, D.J.; Scheible, W.R.; Udvardi, M.K.; Kazan, K. Repressor- and Activator-Type Ethylene Response Factors Functioning in Jasmonate Signaling and Disease Resistance Identified via a Genome-Wide Screen of Arabidopsis Transcription Factor Gene Expression. Plant Physiol. 2005, 139, 949-959. [CrossRef]

88. Thatcher, L.F.; Powell, J.J.; Aitken, E.A.; Kazan, K.; Manners, J.M. The Lateral Organ Boundaries Domain Transcription Factor LBD20 Functions in Fusarium Wilt Susceptibility and Jasmonate Signaling in Arabidopsis. Plant Physiol. 2012, 160, 407-418. [CrossRef]

89. Thatcher, L.F.; Manners, J.M.; Kazan, K. Fusarium oxysporum hijacks COI1-mediated jasmonate signaling to promote disease development in Arabidopsis. Plant J. 2009, 58, 927-939. [CrossRef]

90. van Kan, J.A.L. Licensed to kill: The lifestyle of a necrotrophic plant pathogen. Trends Plant Sci. 2006, 11, 247-253. [CrossRef]

91. Mengiste, T. Plant Immunity to Necrotrophs. Annu. Rev. Phytopathol. 2012, 50, 267-294. [CrossRef]

92. Wan, R.; Hou, X.; Wang, X.; Qu, J.; Singer, S.D.; Wang, Y.; Wang, X. Resistance evaluation of Chinese wild Vitis genotypes against Botrytis cinerea and different responses of resistant and susceptible hosts to the infection. Front. Plant Sci. 2015, 6, 1-17. [CrossRef]

93. Temme, N.; Tudzynski, P. Does Botrytis cinerea Ignore $\mathrm{H}_{2} \mathrm{O}_{2}$-Induced Oxidative Stress During Infection? Characterization of Botrytis Activator Protein 1. Mol. Plant Microbe Interact. 2009, 22, 987-998. [CrossRef]

94. Kloek, A.P.; Verbsky, M.L.; Sharma, S.B.; Schoelz, J.E.; Vogel, J.; Klessig, D.F.; Kunkel, B.N. Resistance to Pseudomonas syringae conferred by an Arabidopsis thaliana coronatine-insensitive (coi1) mutation occurs through two distinct mechanisms. Plant J. 2001, 26, 509-522. [CrossRef]

95. Brooks, D.M.; Bender, C.L.; Kunkel, B.N. The Pseudomonas syringae phytotoxin coronatine promotes virulence by overcoming salicylic acid-dependent defences in Arabidopsis thaliana. Mol. Plant Pathol. 2005, 6, 629-639. [CrossRef]

96. Block, A.; Schmelz, E.; Jones, J.B.; Klee, H.J. Coronatine and salicylic acid: The battle between Arabidopsis and Pseudomonas for phytohormone control. Mol. Plant Pathol. 2005, 6, 79-83. [CrossRef]

97. Cui, J.; Bahrami, A.K.; Pringle, E.G.; Hernandez-Guzman, G.; Bender, C.L.; Pierce, N.E.; Ausubel, F.M. Pseudomonas syringae manipulates systemic plant defenses against pathogens and herbivores. Proc. Natl. Acad. Sci. USA 2005, 102, 1791-1796. [CrossRef]

98. Melotto, M.; Underwood, W.; Koczan, J.; Nomura, K.; He, S.Y. Plant Stomata Function in Innate Immunity against Bacterial Invasion. Cell 2006, 126, 969-980. [CrossRef]

99. Underwood, W.; Melotto, M.; He, S.Y. Role of plant stomata in bacterial invasion. Cell. Microbiol. 2007, 9, 1621-1629. [CrossRef]

100. Felix, G.; Duran, J.D.; Volko, S.; Boller, T. Plants have a sensitive perception system for the most conserved domain of bacterial flagellin. Plant J. 1999, 18, 265-276. [CrossRef]

101. Alexander, C.; Rietschel, E.T. Invited review: Bacterial lipopolysaccharides and innate immunity. J. Endotoxin Res. 2001, 7, 167-202. [CrossRef]

(C) 2018 by the authors. Licensee MDPI, Basel, Switzerland. This article is an open access article distributed under the terms and conditions of the Creative Commons Attribution (CC BY) license (http:/ / creativecommons.org/licenses/by/4.0/). 